\title{
Demokrasi Islam dalam Pandangan Muhammad Natsir dan Muhammad Abid Al-Jabiri
}

\author{
Tomi Agustian \\ Dosen Institut Agama Islam Negeri Curup \\ Tomiagustian48@iaincurup.ac.id
}

\begin{tabular}{ll}
\hline \multicolumn{1}{c}{ Abstrak } \\
\hline Article History & Muhammad Natsir is an Indonesian thinker and \\
Received :17-02-2020 & politician, including those who take note. He prefers to \\
Revised :19-02-2020 & combine the concept of Western democracy with Islamic \\
Accepted :28-02-2020 & values, thus bringing up the concept of theistic \\
\hline Keywords: & democracy. While on the other hand there is Muhammad \\
Islamic Democracy & Abid al-Jabiri who feels that democracy is a 'necessity' \\
Muhammad Natsir's & for every nation. The argument he built was not because \\
View and Muhammad & of the compatibility between democracy and Islam, but \\
Abid al-Jabiri & rather because of the reality faced by the Arabs. Natsir \\
& and al-Jabiri were religious nationalists who fought for \\
& democracy. Because this research is a study of the \\
& history of thought, the approach used is a socio- \\
& historical approach, which is an approach used to \\
& determine the socio-cultural and socio-political \\
& background of a character, because the thought of a \\
& character is the result of interaction with the \\
& environment. Natsir uses the reconstruction method \\
& while al-Jabiri uses the deconstruction method. Both are \\
& included in the category of reformistic typology thinkers, \\
& namely those who believe that turâs and modernity are \\
& both good. Therefore, trying to harmonize tour and \\
& modernity by not violating common sense and rational \\
standards. & \\
\hline
\end{tabular}

\section{Pendahuluan}

Demokrasi adalah sebuah sitem pemerintahan yang hampir sebagian negara dibelahan dunia menggunakan sistem tersebut, demokrasi dalam dalam istilah modern, telah dipercaya dan memperoleh kepercayaan sebagai sitem yang terabaik hampir dan universal sebagai ide dalam politik dan telah menjadi sebagai sebuah ideologi.(Franz Magnis Suseno, 1996:122),Hal ini menunjukkan bahwa demokrasi sebagai bagian dari modernitas merupakan sistem perpolitikan yang diidealkan oleh setiap penduduk negeri di seluruh belahan dunia. Modernitas ini direspon berbeda oleh setiap negara Muslim di dunia. Paling tidak, Ada dua kecenderungan besar (mainstream sikap di antara cendikiawan Muslim dalam melihat modernitas, yaitu pertama, yang menentang mentah-mentah (disebut fundametalis dan kedua, yang menerima mentah-mentah tanpa pertimbagan tradisi (disebut apologetis.( Sikap tersebut secara jelas telah ditunjukkan oleh beberapa belahan negara Muslim seperti Iran, Pakistan, dan Saudi Arabia yang megklaim sebagai negara Islam. Sementara di sisi lain ada Mesir dan Turki yang telah berubah menjadi negara sekuler. 
Turki menjadi negara sekuler setelah keruntuhan dinasti Ottoman. Sekulerisasi yang terjadi di Turki dimotori oleh Mustafa Kemal dengan melakukan perubahan radikal (revolusi terhadap negaranya yang meliputi bentuk negara, sistem pemerintahan, politik, budaya sampai kepada bahasa yang digunakan.Demikian pula halnya dengan Mesir yang telah menjadi negara liberal (sekuler yang memisahkan agama dan negara. Tokoh intelektualnya yang paling terkemuka dalam masalah ini adalah Syaikh Ali Abd ar-Raziq. Raziq memiliki pandangan bahwa Islam dimaknai sebagai sebuah agama sebagaimana dalam pandangan politik Barat yang memisahkan agama dan negara.(Munawir Syadzali, 1993:1-3) Berbeda dengan negara-negara di atas adalah Indonesia dan Maroko yang malu-malu untuk menyatakan diri sebagai negara Islam maupun negara sekuler. Keduanya adalah negara berpenduduk mayoritas Muslim dan pernah menjadi jajahan bangsa Eropa, yang satu bekas jajahan Belanda dan yang lain jajahan Perancis. Pengaruh Eropa Belanda dan Perancis cukup meninggalkan bekas di kedua negara itu terutama budaya dan sistem pemerintahannya. Begitupun dengan demokrasi yang muncul di belahan bumi Eropa itu. Demokrasi menjadi "barang laku" di berbagai negara, meskipun kelahirannya tidak sekaligus membawa suatu bangsa menjadi lebih baik.

Di Indonesia demokrasi telah menjadi pilihan sistem kenegaraannya, meskipun dengan modifikasi lain dan beberapa catatan. Polemik tersebut dimulai oleh Sukarno yang menulis artikel "mengapa Turki Memisahkan Agama dari Negara?" Artikel itu menunjukkan keberpihakannya terhadap gagasan sekuler yang di gencarkan Mustafa Kemal dan Ali Abd ar-Raziq. Tulisan tersebut direspon oleh banyak tokoh politik Islam saat itu, seperti H. Agus salim, H.O.S. Cokroaminoto dan Muhammad Natsir.(Ahmad Suhelmi, 2002:5-6) Natsir memiliki pandangan para reformasi Muslim berkeyakinan bahwa Islam tidak dapat dipisahkan dari negara islam ituadalah ajaran-ajaran yang meliputi kaidahkaidah muamalah (hubungan manusia dengan sesamamanusia dan ibadah khusus (hubungan manusia dengan Tuhan. Negara menurut pendapat Natsir hanyalah merupakan alat untuk merealisasikan syari'at Islam dan bukan merupakan tujuan.(Muhammad Natsir, 2001:83)

Oleh karena itu, menurut Natsir, untuk mengatur negara dan masyarakatnya, maka Islam harus menjadi ideologi negara. Ideologi dalam pengertiannya bukan hanya suatu ide, tetapi merupakan suati aliran tertentu. Berangkat dari pandangannya itu bahwa agama dan negara harus bersatu, secara rinci prosedural, ia memilih demokrasi sebagai sebuah sistem politik yang mempunyai nilai-nilai yang hampir sama dengan Islam. Karenanya, dia mengusulkan bagi bentuk negara dan sistem pemerintahan Indonesia adalah "Negara Demokrasi Berdasarkan Islam".Natsir pernah mengemukakan bahwa sejauh menyangkut dengan umat Islam, demokrasi adalah hal yang paling pertama dan terabaik, karenaIslamakan berhasil jika menggunakan sebuah sistem yang demokratis.(Ahmad Suhelmi, 2002:128). Natsir adalah seorang demokrat. Ia bersikap kritis dan tidak senang dengan tindakan politik diktatorial. Perjalanan politiknya sebagai seorang politikus dan negarawan, terutama ketika menjadi perdana menteri (1950-1951, telah membuktikan hal tersebut. Dengan pemikiran dan perjuangannya itu, dapat dikatakan bahwa Natsir adalah seorang nasionalis religius Islami.yang mayoritas 
Negara yang hampir sama dengan Indonesia adalah Maroko, yang merdeka tahun 1965. Di sana demokrasi masih menjadi perdebatan serius sampai saat ini. Tokoh kontemporer yang namanya cukup dikenal adalah seorang M. 'Abid alJabiri, seorang intelek Muslim asal negeri itu yang sedang gigih berjuang dalam proyek besarnya dalam sebuah bukunya yang berjudul "Kritik Nalar Arab". AlJabiri berbeda dengan Natsir. Menurutnya, bahwa pertanyaan "apakah Islam itu adalah sebuah, agama atau sebuah negara?" tidak ada persamaannya maknanya dalam Islam, karena memisahkan agama dari negara sama sekali tidak sejalan dengan kerangka rujukan pemikiran Islam.(Muhammad 'Abid al-Jâbirî, 1994: 6263) Artinya tema antara agama dan negara tidak pernah dibahas pada zaman Rosulullah dan al-Khulafâ' al-Râsyidûn. Ia tidak menganggap bahwa konsep syûrâ dalam sistem Islam tersebut sama dengan sistem demokrasi. secara ahistoris, sistem syûrâ pada awalnya hanya seabagai konsultasi yang tidak mengikat seorang pemimpin untuk menjalankan hasil konsultasi tersebut.(AlJâbirî, 1994:42)sedangkan berbeda dengan sistem demokrasi yang menganggap bahwa keputusan dari wakil rakyat yang dipilih bersifat mengikat.

Al-Jabiri menggunakan tiga kerangka konseptual dalam penafsirkan teks dalam al-Qur'an dan dalam hadits, Pertama adalah yang dipikirkan (al-mufakkar fìh, kedua adalah yang tak terpikirkan (allâ mufakkar fîh, dan yang ketiga adalah yang terbuka untuk dipikirkan (qâbil li at-tafkîr fîh. Dalam konsep sistemsyûrâ apa yang dipikirkan itu pada awalnya adalah sebuah konsultasi yang tidak mengikat yang diwakili oleh bebrapa orang, sedangkan dalam sistem demokrasi melalui sistem pemilihan umum merupakan sesuatu yang tidak terpikirkan dimasa itu. Dalam hal lain sistem konsepsyûrâ itu terbuka untuk dapat dipikirkan, dan dapat juga ditafsirannya menjadi sebuah konsep dalam sistem demokrasi seperti sekarang, sesuai dengan perkembangan masyarakat Muslim kontemporer. Karenanya, ia juga mendekonstruksi konsep demokrasi yang telah ada dengan mengatakan bahwa definisi demokrasi sebagai pemerintahan rakyat atas dirinya sendiri merupakan definisi yang tidak mungkin dapat diterapkan. Al-Jabiri meyakini bahwa demokrasi akan bisa menyelesaikan persoalan krisis di negaranegara Arab, sehingga ia menginginkan adanya persatuan bangsa-bangsa Arab. Persatuan bangsa-bangsa Arab bukan dalam artian harus adanya satu kepemimpinan untuk seluruh negara, melainkan adanya kepentingan yang sama dalam rangka keluar dari berbagai kungkungan krisis dan tirani kapitalisme dan untuk mensejahterakan rakyat. Dengan demikian, ia dapat dikatakan sebagai seorang nasionalis Arab.(Ahmad Baso, 1999:9) Natsir dan al-Jabiri adalah sosok pemikir Muslim yang menyetuji sistem demokrasi dan nilai yang dikandungnya, agar tercapai sebuah masyarakat yang berkeadilan. Dari sisi ini sepertinya pemikiran politik Natsir dan al-Jabiri sama-sama berjuang untuk negaranya masing, situasi dan waktu pada zamannya yang berberda. Sehingga memberikan kesempatan kepada penulis untuk menganalisis pemikiran para tokoh intelektual tersebut.

Masalah demokrasi merupakan hal yang sudah sejak lama disukai untuk dbiahas baik secara teori, konseptual historis hinggaempiris kedekatan sosiologis. tetapi, karya tulis tentang demokrasi yang mengenai pemikiran M. Natsir dan M. al-Jabiri, sejauh yang penulis baca, belum samasekali ditemukan. walaupun, ada beberapa karya tulis yang membahas pandanganM. Natsir mengenai politik dengan tokoh lain, di salasatunya: Prof. Yusril Ihza Mahendra, dalam sebuah 
disertasi doktormembahas Modernis dan Fundamental didalam sebuah pemikiran Politik dalam Islam, dalam dikursus Partai Masyumi (Indonesia) dengan Jamaati Islam (Pakistan).(Yusril Ihza Mahendra, 1999:48)dalam sebuah karya tulis disertasi Yusril Iza Magendra ini lebih membahas pada gerakan kedua partai tersebut, partai Masyumi, Jamaat-i Islami ideologi yang perjuangannya langkahlangkah yang ditempuh oleh kedua partai yang masing-masing dimotori oleh Natsir (modernis) dan al-Maududi (fundamentalis). (Kamaruzzaman Bustaman., 2002;34)

Adapun sebuah skripsi Ahmad Suhelmi. Yang menjelaskan pandanganpandangan politik Natsir di Indonesia dan membandingkan Sukarno pada sebuah konsep dasar negara Indonesia terhadap sebuah agama (Islam). Sedangkan beberapa skripsi antara lain: Pemikiran Muhammad Natsir tentang sebuah konsep Negara Negara Berdasarkan Ideologi Islam),(Fauzan Rofiqun, Pemikiran Muhammad Natsir tentang Negara (Telaah Negara Berdasarkan Ideologi Islam Yogyakarta (2000:49)membahas dengan cukup singkat dan global pemikiran Natsir tentang negara.Lalu Muhammad Natsir dan Gagasannya tentang Ideologi Negara Islam.Ummu Salamah, Muhammad Natsir dan Gagasannya tentang Ideologi Negara Islam, skripsi tidak diterbitkan, (Ummu Salamah, 1995;65)Ummu Salamah, M Natsir dan Gagasannya tentang Ideologi Negara Islam, skripsi, (Yogyakart pada Fakultas Adab UIN Sunan Kalijaga, 1995)dan Gagasan Tentang Islam sebagai Dasar Negara dalam Majlis Konstituante: Studi Perjuangan Politik Muhammad Natsir 1957-1959,(aenal Arifin, 2002:15).Yang dibahas dalam dua skripsi tersebuthanya terbatas pada masalah ideologi kedua tokoh tersebut.Melihatyang telah Natsir perjuangkan dalam kontribusiuntuk bangsa Indonesia melalui parlemen dibahas dalam Mosi IntegralistikM. Natsir dalam Kembali Negara Kesatuan Republik Indonesia.Ahmad Bawaki, Mosi Integral Natsir dalam Pembentukan sebuah Negara Kesatuan Republik Indonesia, skripsi (pada Fakultas Syari'ah IAIN Sunan Kalijaga, 1999: 25) dalam skripsi tersebut tidak membahas mengenai Natsir dan konsep demokrasinya dan monoton. Ahmad Bawaki,

Menulis mengenaiM. al-Jabiri dalam sebuah artikel,oleh A. Luthfi Assyaukanie, Tipologi dan Wacana Pemikiran Arab Kontemporer menempatkan M. al-Jabiri sebagai tipologi reformistik bersama-sama M. Arkoun yang dalam metode dekonstruktif. Syafiq Hasyim menulis artikel "Problematika Islam dan Politik: Perspektif Kritik Nalar Politik M. Abid al-Jabiri, "Problem Islam dan Politik: Perspektif Kritik Nalar Politik Muhammad Abid al-Jabiri," dalam Jurnal Tashwirul Afkar, No. 4, (1999; 29-39).

\section{Metode Penelitian}

Dalam Penelitian tersebut adalah penelitian pustaka (library research), yang mendapatkanbuku-buku sebagai sumber tulisannya.(Sutrisno Hadi, 1990:9).Penelitian ini bersifat penelitian ini adalah deskriptif analisis komparatif. (Sudarto, 1996: 47).Metode Pengumpulan Data-data ini adalah kajian kepustakaan, sehingga sumber datanya ialah sebuah karya-karya yang diperjuangkan oleh kedua tokoh tersebut, atau disebut juga dengan data utama (primer). Sedangkan sumber bantuan atau tambahan (sekunder) adalah kajiankajian yang membahas tentang demokrasi, dan yang membahas kedua tokoh tersebut.Analisis DataJika data telah terkumpul, dilakukan analisis data secara 
kualitatif dengan menggunakan instrumen analisis deduktif dan interpretataif.(Sudarto, 2001:42). Pendekatan dalam penelitian ini menggunakan Pendekatan sosio-historis, yang digunakan untuk mengetahui latar belakang sosiokultural dan sosio-politik seorang tokoh, karena pemikiran seorang tokoh merupakan hasil interaksi dengan lingkungannya itu.(Atho' Mudzhar, 1998: 105).

\section{Pembahasan}

\section{Teori Demokrasi}

Demokrasi dalam pengertian rakyat berkuasa atau government or rule by the people (dalam bahasa Yunani, demos berarti rakyatcratos/cratein berarti kekuasaan/berkuasa).(Miriam Budiarjo, 1999: 50) demokrasi liberal demokrasi ialah memiliki keputusan politik dalam setiap individu memiliki kekuasaan untuk memutuskan dengan dengan cara yang perjuangan suara rakyat. Hook, Philippe C. Schmitter dan Terry Lynn Karl menganggap demokrasi menjadi sistem pemerintahan yang mana pemerintah diminta bertanggung tanggung jawab atas apa yang mereka lakukan di hadapan publik untuk warga negara yang kerjasama dengan wakil dari yang dipilih.(Masykuri Abdillah,1999: 72) Deliar Noer, menganggap demokrasi sebagai dasar hidup untuk bernegara memberi pengertian bahwa pada tingkat terakhir rakyat memberikan ketentuan dalam masalahmasalah pokok yang mengenai kehidupannya, termasuk dalam menilai kebijaksanaan negara, oleh karena kebijaksanaan itu menentukan kehidupan rakyat.(Deliar Noer, 1983: 207) Sementara itu, Henry B. Mayo memberikan pengertian sistem politik demokrasi yang menunjukkan mengenai kebijakan umum ditentukan mayoritas wakil-wakil yang diawasi s(Moh. Mahfud MD, 1993:19).

Beberapa definisi di atas mengimplikasikan bahwa demokrasi mengandung beberapa unsur, antara lain: 1)rakyat terlibat langsung dalam pengambil kebijakan politik, 2) adanyan penyamaanantara hak warga negara, 3) kebebasan dalam kemerdekaan diberikan dan dipertahankan oleh setiap warga negara, 4) menggunakan perwakilan 5) menggunakan konsep pemilihan ketentuan mayoritas.(Lyman Tower, 1987: 29) Keterlibatan rakyat sebagai unsur pertama mengimplikasikan adanya dua model demokrasi: a) yaitu demokrasi secara langsung, rakyat dilibatkan dalammengambilkeputusan secara pribadi dalam keputusan politik dan ikut serta membahas dan mensahkan undang-undang, dan b) demokrasi perwakilan, yaitu rakyat memilih warga lainnya untuk membahas dan mensahkan undang-undang. Di samping pembagian tersebut (langsung dan perwakilan), ada dua pendekatan lain yaitu teori elitis dan teori partisipasi mengenai keterlibatan rakyat. Teori partisipasi menyatakan bahwa diperlukan tingkat partisipasi rakyat yang tinggi, menciptakan kembali demokrasi langsung. Sebaliknya, teori elitis mengatakan bahwa demokrasi adalah suatu metode untuk mengambil keputusan yang akan menjamin efisiensi dalam pemerintahan dan pengambilan keputusan dan karena itu membutuhkan ketanggapan dari elit penguasa terhadap opini masyarakat. Menurut pendekatan ini keterlibatan rakyat berfungsi sebagai suatu pengendalian terhadap tindakan para elit dan juga untuk mempertahankan persaingan di antara elit-elit yang bersaing. 
Unsur kedua dari demokrasi adalah persamaan hak (equality) yang meliputi kesamaan hak dalam politik, adanya kesamaan dihadapan hukum, dan sekaligus mendapatkan kesempatan dalam ekonomi, sosial. Mengenai kebebasan dan kemerdekaan sebagai unsur yang ketiga dari demokrasi, secara spesifik meliputi: 1) hak untuk memilih, 2) kebebasan mengeluarkan pendapat, 3) kebebasan pers, 4) kebebasan beragama, 5) kebebasan dari perlakuan semena-mena oleh sistem politik dan hukum, 6) kebebasan bergerak, berkumpul dan berserikat. Sedangkan unsur keempat demokrasi adalah sistem perwakilan. Salah satu masalah pokok dalam demokrasi perwakilan adalah keinginan beberapa ahli teori untuk menyamakan demokrasi perwakilan dengan demokrasi langsung. Di Amerika Serikat sistem seperti inisiatif, referendum dan recall telah dikembangkan sebagai alat untuk memungkinkan seluruh rakyat memainkan peranan langsung dalam pengambilan keputusan politik. Menurut Jean-Jacques Rousseau, wakil atau utusan rakyat bukanlah dan tidak dapat menjadi wakil rakyat. Mereka, kata Rousseau, hanyalah agen rakyat dan tidak dapat mengambil keputusan final. Setiap hukum yang yang belum diratifikasi oleh rakyat sendiri adalah batal, dan sama sekali bukan hukum.(Sumardjo, 1986:85).

Terakhir, unsur yang kelima dari demokrasi adalah sistem pemilihan. Sistem pemilu, walaupun kelihatannya hanya merupakan suatu mekanisme untuk menentukan komposisi pemerintah beberapa tahun yang akan datang, sebenarnya merupakan sarana partisipasi politik yang utama dan kadang satu-satunya cara, maka ia merupakan kunci bagi apakah pemilunya demokratis atau tidak. Pembahasan tersebut di atas dapat dikatakan dalam kontemporer demokrasi diartikan pragmatis dibanding filosofis.(Masykuri, 1999: 73)

Membahas demokrasi, M. Natsir memiliki berpandangan prinsip Islam mengenai sistem syûrâ yang dikenal dalam islam sangat mendekati dalam dengan sistemdemokrasi dalam pengertian modern saat ini, demikian Natsir juga berpendapat teori dalam kedaulatan rakyat dan kedaulatan Tuhan. Natsir berpendapat bahwa Islam menganut suatu paham theistic democracy, atau disebut demokrasi dalam pengertian memiliki nilai ketuhanan. Karena dipilih oleh Sebagian mayoritas rakyat tersebutlah tidak lepas dari campur tangan ketuhanan, pandangan Natsir tersebut, disebut sebagai ijma' kaum Muslimin yang dapat mengikat seorang pemimpinyang akan datang yang terpilih melalui pemilihan tersebut.(Thohir Luth, 1999: 22). Sama halnya dengan al-Jabiri yang mengakui bahwa demokrasi tidak sama sekali berarti suatu pengabaian terhadap Islam. Sesungguhnya pertimbangan obyektiflah yang mendorongnya untuk berpendapat bahwa jika orang-orang Arab adalah materi maka Islam adalah ruhnya orangorang Arab. Dari sini muncul satu keniscayaan untuk menjadikan Islam sebagai fondasi bagi eksistensi Arab: Islam secara spiritual bagi Arab yang Muslim dan Islam sebagai peradaban bagi Arab yang Muslim dan non-Muslim. Namun demikian M. al-Jabiri juga mengingatkan kita untuk tidak menggunakan agama untuk tujuan politik tidak benar karena agama tersebut bersifat permanen sedangkan politik berubah-ubah,: karena politik digunakan untukkepentingan beberapa individu maupun kelompok yang memiliki kepentingan, sedangkan agama adalah kepentingan dunia dan akherat. . hal tersebutla ditakutkan oleh M. al-Jabiri jika agama dicampur adukan dengan negara. (Imam Khoiri, 1999: 234) 
Akan tetapi, bagi M. Natsir negara yang menyatu dengan Islam bukan sebuah negara teokrasi, dapat disebut negara demokrasi dan bukan pula sekuler. Singkatnya, dapat disebut sebagai negara demokrasi dalam pandangan Islam atau disebuttheistic democracy.Bagi M. Natsir, demokratis dalam pengertian Islam adalah anti alistimbat(despotisme), anti absolitisme anti penyalagunaan sewenangwenangan. Artinya, demokrasi diartikan dapat pula diartikan secara substansial dan bukan bukan demokrasi secara formal yang ada pada tradisi Barat.(Ichlasul Amal, 2018:61) Dalam hal tersebut al-Jabiri juga tidak sepakat terhadap demokrasi dalam pengertian Barat saat ini, yang berarti kebebasan politik dan kebebasan ekonomi (liberalisme) tanpa adanya pembatasan terhadap kebebasan dan perilakunya, dan tanpa adanya control dari sisi manapun terhadap kegiatan ekonomi tersebut. Menurutnya, hal itu akan meniadakan demokrasi itu sendiri, karena kebebasan politik dan kebebasan ekonomi hanyalah kebebasan bagi mereka yang mempunyai modal, rakyatpundalam memahami demokrasi mengakibatkan rakyat tidak begitu memberikan perhatian terhadap demokrasi politik tersebut. Menurut al-Jabiri demokrasi melalui pemilihan yang dapat digunakan pemerintah untuk tujuan mencapai keadaan yang disebut tirani, ketidakadilan, dan pemihakan itu hilang sehingga terwujudlah persamaan. Untuk mewujudkan ini bergantung pada kadar kemampuan rakyat untuk memilih.(Muhammad Abid al-Jabiri, 2000: 28)

M. Natsir berpandangan bahwa, sistem demokrasi tidak sama dengan sistemkomunisme, karena Islam dalam islam mengakui hak-hak yang dimilikioleh individu-individu dan sistem demokrasi memiliki kebebasan, sehingga wajib kepada setiap orang untuk dapat bekerja keras. Dan demokrasi juga tidak sama dengan sistem kapitalisme, karena harta kekayaan yang dimiliki itu tidak diperbolehkan untuk kepentingan individu saja, melainkan digunakan dan disberikan sebagian untuk tolong menolong sesamanya, untuk dapat mendapatkan tujuan yaitu keadilan dan kemakmuran sesama manusia.

Natsir berpandangan bahwa sistem demokrasi itu baik, namun dalam sistem negara dalam Islam tidak semua urusannya dapat melalui sistem demokrasi, karena demokrasi tidak selaludapat diterapkan dalam berbagai hal dan masalah. Dengan melihat sejarah demokrasi dari beberapa abad sudah menunjukan beberapa hal yang baik. Namun, dalam sistem demokrasi yang sudah sangat bebas juga dapat membahayakan bagi sebuah negara. Bahaya itu dalam pandangan M. al-Jabiri, karena demokrasi untuk kepentingan politik dapat dimampaatkan para penguasa atau orang-orang yang kaya kapitalispemilik modal yang berkuasa.Dan bila hal tersebut terjadi maka hal tersebut harus diperangi. Demokrasi politik dapat memberikan peluang bagi banyak otrang untuk mendapatkan simpati rakyat terhadap hakikat konflik sosial. Dalam sebuah lembaga parlemen, yang dimiliki partai politik dan kebebasan dan mengikuti pemilu, hal tersebut merupakan peluang yang dapat dimungkinan- demokrasi untuk menyadarkan massa pemilu yaitu rakyat dalam memperjuangkan hak-hak mereka tersebut.(Mujiburrahman, 2003: 212), Berbeda dengan al-Jabiri, menurut Natsir sistem dan struktur yang ada dalam negara demokrasi tidak menjamin bahwa sebuah negara akan demokratis namun, terletak pada tegaknya "keadilan" dalam hidup bermasyarakat rasa keadilan adalah hal yang diharapkan oleh setiap manusia. Jadi, demokrasi membuat seseorang merasa dihargai karena dapat menentukan pilihannya dalam Pemilu. (Yusril Ihza Mahendra, 1999: 13) 
Di samping itu, Natsir menegaskan bahwa meskipun demokrasi menganggap tidak mungkin pengambilan keputusan secara mayoritas atau musyawarah,tidak semua hal melalui sistem pemerintahan dapat diputuskan dalam musyawarah majlis syura. Begitun dalam parlemen dinegara Islam, yang hanya dapat dimusyawarahkan abagaimana tata cara melaksanakan hukum Islam dimasyarakat.

\section{Argumentasi Pemikiran}

Natsir berpendapat bahwa interpretasi yang paling modern tentang demokrasi hanya bisa didapat dalam Islam dan tidak begitu banyak terdapat dalam praktekpada jaman saat ini, baik di politik di Barat, dan juga di Timur. M. Natsir berpendapat bahwa agama bukan hal yang membahayakan untuk dihindarkan karena agama dapatmerupakan hal terpenting untuk mempererat hubungan manusia dengan manusia lainnya. Hal tersebut didasakan pada konsepnya mengenai relasi Islam dan negara. Islam tidak dapat dilepaskan dari negara. Karena urusan negara merupakan hal yang integral dalam risalah ajaran Islam. M. Natsir mengutip ayat al-Qur'an beberapa ayat al-qur'an sebagai dasar idiologi dalam Islam: "tidak aku ciptakan mahkluk jin dan manusia melainkan untuk beribadah kepadaKu”. Dalam ayat tersebut maka dijadikan dasar ideologi dalam Islam, ksimpulan bahwa seorang Muslim ini hanyalah untuk mengabdi kepda Allah, untuk mencapai kebahagian di dunia dan kebahagian di akherat. Sehingga Allah tersebut, Allah memberikan aturan yang berupa hukum itu untuk manusia agar melaksanakan apa yang dioperintahkan dan menjauhi apa yang dilarangnya.

M.Natsir memandangbahwa sistem demokrasi yang diinginkan Islam tersebut sama hampirsama dengan demokrasi liberal, yang berbeda hanya dalam mengambil keputusan politik, atas konsep iljtihad, syuromaupunmelalui ijma'.Konsep ijtihâd dan ijmâ' jika dihubungkan dengan konsep syûrâ yang disebutkan dalam al-Qur'an, menurut Natsir, dapat diwujudkan ke dalam bentuk parlemen yang anggota-anggotanya dipilih oleh seluruh rakyat. Mereka yang menerima amânah dari seluruh rakyat itu, dengan berpandu kepada asas-asas doktrin, dapat membuat berbagai kebijaksanaan politik, hukum dan keputusan politik lainnya berdasarkan kepada suara mayoritas. Landasan pandangannya ialah salah satu hadits Nabi, "umatku selamanya tidak akan pernah bersepakat di dalam kesalahan". Al-Jabiri berpendapat bahwa penyatuan agama dalam sebuah negara itu tidak pernah disampaikandi zaman rosul/nabi dan tidak perna juga pada zaman al-Khulafa ar-Rasyidin.' Ia juga tidak dengan mudah mengatakan bahwa demokrasi sama atau ada dalam tradisi Islam. Menurutnya sistem demokrasi menentukan dua hal yang berbeda di antara kedua-nya yang mengungkapkan realitas kekinian masyarakat Arab, itu merupakan tradisi dan dari zaman renaissans. yang menganggap demokrasi sama dengansistem syuro(musyawarah) dalam demokrasi islam dan selanjutnyaunsur demokrasi sangat perjuangan di Eropa.

Menurut al-Jabiri, keengganan menggunakan kata-kata asing merupakan pantulan dari sikap ideologis populer, yang semakin mengarah pada pemutusan hubungan dengan otoritas renaissans Eropa. Gejala inilah yang kita temukan pada generasi kedua gerakan salafiyah. Sedangkan dalam diri para pionir gerakan ini, seperti al-Afgani dan 'Abduh, kita temukan keinginan yang kuat untuk menjembatani antara kedua otoritas itu: tradisi Arab Islam dan tradisi renaissans 
Eropa.

\section{Metode Pendekatan}

Metode pemikiran Natsir dan al-Jabiri sebetulnya memiliki kecenderungan yang sama, yakni lebih menekankan kepada hal-hal yang substansial daripada bentuk atau formalitas belaka. Pemikiran Natsir dalam hal pengaturan negara tidak rigid sebagaimana kaum fundamentalis. Ia tidak memperjuangkan Negara Islam secara formal dengan nama Islam dan hukum Islam secara ketat. Yang diperjuangkannya ialah bagaimana negara diatur dengan prinsip-prinsip ajaran agama Islam. Hal ini harus dibedakan antara yang prinsip ajaran dengan yang bukan prinsip (hukum formal Islam). Demikian pula halnya dengan al-Jabiri, meskipun ia tidak membahas hubungan agama dan negara, akan tetapi ia juga mengatakan bahwa Islam adalah ruh bagi orang Arab Muslim, dan peradaban bagi semua orang Arab. (Ahmad Baso, 2000: 35) Namun demikian, metode berpikir yang sama tersebut, pada kenyataannya mempunyai perbedaan dalam hal metode pendekatan yang digunakan dalam memahami nas teks dalam alqur'an dan teks dalamassunnah. Metode pendekatan yang digunakan oleh M. Natsir konsep rekonstruktif, dengan memperhatikan tradisi secara untuk pembangunan. Yaitu supaya tradisi dalam sebuah masyarakat yang beragam tetap bertahan hidup dan tetap dapat bisa diterima di masyarakat, hharusnya membangun dengan cara baru (iadah bunyah min jadid) dalam kerangka yang modern dan sebagai syarat rasional. Pandangan ini berbeda dengan tradisi tradisional yang menjadi prioritas metode tradisi yang digunakan di masa lalu. Yang berpendapat seluruhmasalah umat Islam menjadi hal yang harus ditentukan oleh para ulama yang terdahulu. sehingga, kaum Muslim sekarang hanya mengikuti apa yang dilakukan oleh pendahulu mereka.(Ali Mudhofir, 1996: 192).

Persoalan pengaturan kenegaraan, menurut Natsir adalah termasuk masalah ijtihâdî, artinya tidak ada nash yang mengharuskan sebuah negara menggunakan suatu sistem poltik tertentu. Jika sekelompok Muslim masa lalu memilih khilafah sebagai satu alternatif sistem politik yang kemudian menjadi mapan, dalam bahasa Imarah, bukanlah pilihan teologis. Dengan kata lain masalah itu hanya didorong unsur-unsur kebutuhan kaum Muslim masa itu yang basis teologisnya -paling kuat- cuma penafsiran. Islam tidak pernah menganjurkan teokrasi. Persoalannya bukan pada persatuan atau pemisahan agama dan negara, melainkan kedua hal itu sangat kompleks, sementara Islam hanya memberikan garis-garis besarnya saja.(Toprak, Binnaz,1999: 110) Dengan penjelasan ini, Natsir ingin menegaskan bahwa persoalan politik dalam Islam harus ditangani secara serius. Keseriusan ini tercermin dalam perjuangannya merumuskan dan menerapkan konsep theistic democracy-nya. Dalam pandangannya ini, Natsir sesungguhnya ingin menafsirkan kembali soal-soal yang bersangkutan dengan sistem kenegaraan Islam tanpa harus membuang tradisi yang ada.

Berbeda dengan Natsir, al-Jabiri menggunakan metode dekonstruktif. Para pemikir dekonstruksionis Arab kebanyakan datang dari daerah Arab Maghribi (Maroko, al-Jazair, Tunis dan Libia). Tampaknya unsur bahasa Perancis warisan kolonialisme yang tersisa di negeri-negeri tersebut menyebabkan kalangan akademisnya lebih menyerap literatur berbahasa Perancis, ketimbang bahasa Eropa lainnya. Keterikatan intelektual para pemikir Arab maghribi dengan Perancis bukan hanya sebatas bahasanya, mereka juga terpengaruh oleh gerakan- 
gerakan pemikiran dan filsafat Perancis kontemporer, khususnya gerakan post strukturalisme. Bahkan, menurut Luthfi Assyaukanie, hampir seluruh pemikir Muslim Maghribi yang concern terhadap keislaman dan kearaban adalah penganut paham strukturalisme; itu karena problem yang mereka hadapi kebetulan sama yaitu masalah bacaan atas tradisi, baik yang berbentuk teks maupun realitas. Dan menurut mereka metode yang paling modern dan paling ampuh untuk membaca tradisi adalah dekonstruksi.

Selama warisan ilmiah menjadi unsur yang terpenting, dan warisan tersebut tertulis dalam bentuk teks, pertanyaan yang diajukan oleh al-Jabiri adalah, bagaimana membaca teks-teks tersebut.? Menurut al-Jabiri masalah tersebut pada akhirnya terbentur pada persoalan otoritas (sulah), yaitu siapakah yang memiliki otoritas dalam menentukan bacaan; pembaca atau bacaan, kita atau turâŝ? Di sini, jelas al-Jabiri, turâs harus dilihat sebagai satu struktur mapan, yaitu sebagai sistem dari hubungan tetap dalam kerangka seluruh perubahan dan transformasi. Karenanya, tambah al-Jabiri, dalam dialektika pembaca dan bacaan, dan soal siapa pemegang otoritas, ada tiga model bagaimana turâs itu harus disikapi; pertama membaca turâs dengan kerangka modernitas; kedua membaca turâs dengan kerangka turâs,; dan ketiga membaca modernitas dengan kerangka turâs. Di antara ketiga pilihan itu al-Jabiri mengambil yang pertama, dengan alasan jika ini tidak cepat dipilihnya, maka otoritas akan berpindah kepada kedua dan ketiga, dan itu terutama yang ketiga- sangat berbahaya. Dengan kata lain, masalah otoritas ini bukan hanya sebatas turâs membaca turâs, tetapi yang lebih berbahaaya adalah mengukur segala sesuatu termasuk modernitas dengan kerangka turâs. Menurut al-Jabiri tradisi dan modernitas datang begitu saja di hadapan kita tanpa ada kuasa kita untuk memilihnya. Keduanya datang dengan kekuatan diskursusnya masingmasing, sebagai tawaran idealis yang otoriter. Turâs datang dari masa lalu lewat pewarisan turun temurun, tak seorangpun mampu menolak warisan dan masa lalu yang tumbuh bersama dalam dirinya. Begitu juga modernitas, ia datang dipaksakan tanpa bisa kita menolaknya. Kita tidak pernah diberi kebebasan untuk memilih salah satu keduanya atau meninggalkannya. karenanya kita harus bersikap kritis terhadap keduanya, kepada turâs dan modernitas dengan seluruh makna kritik.

\section{Tipologi Pemikiran}

Dalam penelitian ini, yang diproyeksikan kepada seorang tokoh, penyusun akan melihatnya dalam kerangka yang ditawarkan oleh A. Luthfi Assyaukanie. Menurutnya, dalam pandangan beberapa pemikiran Islam konteporer mengenai kebiasaan dan doktrin agama islam dan politik, ada tiga hal teori yang membahas pemikiran dalam Islam saat ini. antara lain: Pertama, tipologi transformatik, kedua tipologi reformisstik, dan yang terakhirtipologi idealtotalistik. Adapun maksud tipologi pertama adalah gerakan pembaruan pemikiran Islam yang menganjurkan dilakukannya proses tranfiormar perubahan dalam masyarakat sebuah Muslim dari budaya yang tradisional patriarkal menjadi budayayang rasional dan cenderung ilmiah. cara pandang agama yang masih mistis yang tidak sesuai dengan nalar logika dan anggapan agama dan tradisi tersebut adalah budaya masa lalu yang tidak lagi sesuai dengan kondisi saat ini, hal tersebut mesti ditinggalkan.(Mujiburrahman, 2003: 8) 
Tipologi reformistik. Pada jenis ini adalah yang yang ingin dibahas adalah reformasi amalalui penafsiran hal-hal yang baru (reinterpretasi), yang cocok dengan kondisi perkembangan zaman saat ini .pehaman ini lebih cenderung keduanya:,yang memakai metode pendekatan dengan menggunakan rekonstruktf, dengan menggunakan tradisi dalam pembangunan perkembangan zaman. supaya tradisi dalam masyarakat yang berbau agama tetap berjalan dan agar terus dapat diterima, sehingga harus dibangun suatu hal secara baru (i'âdah bunyah min jadîd) dengan kerangka modern dan prasyarat rasional.tipologi reformistik ini ialah menggunakan cara dekonstruktif dan dipakai pada awalnya ialah analisa. menganalisameneruskan sesuatu yang sudah baik dan belajarmenghubungkan beberapaelemen guna penyatuan sebuah bangunan tersebut. (Ahmad Baso, , 2000:35) Dalam kerangka tipologi ini, nampaknya M. Natsir dan M. al-Jabiri dapat dikategorikan sebagai pemikir reformasi. tipologi reformistik ialah cenderung yakin bahwa turasdan modern kedua hal tersebut adalah baik. Yang menjadi sebuah problem ini mencari cara menyelesaikan kedua hal dengan cara yang adil dan bijak. Tidak salah mengutakan satu hal dtidak sesuai dengan yang lain, karena kalau mau jujur, kedua-duanya bukan milik kita, turâs yang dimilikioleh orang pada masa lalu dan modernirtas yang dimiliki orang Barat. Seorang reformistik harus bisa mengharmonisasikan keduanya dengan tidak menyalahi akal sehat dan standar rasional, inilah inti dari reformasi Pemikiran Natsir dapat dikatakan banyak mempengaruhi generasi pembaharu Islam Indonesia berikutnya seperti Amien Rais dan Syafi'i Ma'arif, yang keduanya adalah tokoh Muhammadiyah. Di sisi lain ada Nurcholish Madjid yang pernah dijuluki sebagai "Natsir Muda" namun belakangan berbalik arah dan berbeda dengan Natsir terutama mengenai konsep ideologi. Tokoh lainnya adalah Deliar Noer, Endang Saefudin Anshari, dan Yusril Ihza Mahendra yang pemikirannya juga dipengaruhi oleh pemikiran Natsir. Mungkin ada banyak lagi tokoh yang pemikirannya dipengaruhi oleh Natsir, namun, karena keterbatasan penyusun hal tersebut belum sempat ditemukan. Berikut ini adalah sekilas mengenai tokohtokoh tersebut dan pemikiran politiknya. (Ahmad Baso, , 2000:65)

Amien Rais sudah sangat akrab dengan pemikiran pembaharuan Islam. Hal ini sejalan dengan pemikiran pembaharuan Natsir yang mengedepankan akal pikiran manusia sebagai fasilitas untuk berijtihad dan menggabungkan kemoderenan (Barat) dengan nilai-nilai Islam. Bagi Amien, Natsir adalah sosok guru yang patut ditiru dan sosok politikus yang harus dicontoh. Hidupnya yang bersahaja, keluhuran pribadinya dan permainan politik yang bersih membuat Amien menganggapnya sebagai guru.

Sedangkan pemikiran politik Amien tampaknya agak sejalan pula dengan Natsir, meskipun tidak sebagaimana Natsir yang memperjuangkan Islam sebagai dasar negara secara formal. bagi Amien ialah negara dapat berjalan dengan etos Islam, guna untuk menegakkan keadilan sosial bagi masyarakat banyak dan menginginkan sebuah masyarakat yang berjuang egaliter, menurut Islam ialahbisa disebut negara yang baik. Perdebatan pemikiran Amien rais berdasarkan pada tauhid menurut pendapatnya semua umat Islam harus berpegang pada dasar tauhid sehingga dari hal tersebut berasal dari ajaran Islam. Hanya menyeluruh aktiv dalam hidup yang berpegang pada tauhid, sehingga umat Islammencapai monoteistime (monotheistic unity) yang meliputi semua bidang dan kegiatan hidup, termasuk di dalamnya kehidupan bernegara dan berpemerintahan. Amien 
yakin betul terhadap demokrasi dan ia tidak melihat adanya pertentangan antara proses demokratisasi dengan ajaran Islam. Katanya, "Setiap kali saya bicara demokrasi, tak sedikitpun ada pretensi untuk berpura-pura dalam diri saya. (M. Amirudin, 2000:65)

Tokoh lain yang hampir sama pemikirannya dengan Amien adalah Syafi'i Ma'arif. Berpendapat al-Qur'an maupun rosultidak mengajarkan penetapan terhadap suatu teori mengenai suatu negara yang mutlak mesti diikuti oleh seluruh ummat Islam di belahan dunia, dan asalkan dalam sistemsyura dijalankan dan dihargai sepenuhnya. Dalam pelaksanaannya harus pula dijelaskan secara tegas posisi syari'ah dalam konstitusi negara. Ma'arif mengaku dengan sistem demokrasi memiliki kelemahan dancenderung lamban samapai saat ini demokrasi dapat dipandang sebagai konsep terbaik yang pernah digunakan manusia dalam sistem bernegara. Sementara di sisi lain Nurcholish Madjid nampaknya dipengaruhi oleh pemikiran-pemikiran Natsir, meskipun ada beberapa perbedaan. Perbedaan itu terletak terutama Islam dan ideologi. Islam adalah agama, sedangkan ideologi adalah ilmu tentang ide yang dibuat manusia. Sehingga menjadikan Islam sebagai ideologi adalah mereduksi terhadap Islam itu sendiri. Akan tetapi, Islam bisa dijadikan sebagai sumber ideologi dan bukan ideologi itu sendiri. Dengan pandangannya ini, Nurcholis mengajukan sekulerisasi. Yaitu untuk membedakan menegani yangsakral dan dengan yangprofan, yang bersifat dunia dan yang ukhrat, yang urusan agama secara mutlak dan urusan politik. Namun demikian ia tetap menghormati Natsir dan menganggapnya sebagai seorang yang universalis. Ia melihat Natsir sebagai seorang nasionalis yang bebas dari ativisme dan nativisme. Ativisme adalah segala sesuatu dari masa lalu yang selalu otentik baik. Pak Natsir, kata Nurcholish, tidak melihat bahwa apapun yang diwariskan masa lalu itu selalu baik. Dan tidak juga beranggapan paham yang berasal dari negeri sendiri adalah baik (nativisme).

Tokoh lain adalah Deliar Noer, yang tetap meyakini dan memperjuangkan sistem politik Islam. Menurutnya, Islam tidak hanya mengajarkan nilai-nilai kehidupan dalam diri pribadi dan masyarakat, tapi juga memilih tegak sebuah cara yang termasuk dalam sistem cara umum. Yang dilakukan pada masa nabi Muhammad sehingga bagi orang Islam mestinya menjadikan contoh. antara lain nilai suatu kebenaran, nilai keadilan, dan nilai kejujuran, amanah danbertaqnggung jawab, baik kata maupun dalam perbuatan, sikap istiqamah (konsisten). Hal Ini menuntut aturan dalam sistem kehidupan bermasyarakat dan bernegara yang telah sesuai dengan tersebut. Sistem tersebut bukanlah kapitalisme maupun komunisme, tapi demokrasi.

Tokoh lain yang dipengaruhi Natsir adalah Yusril Ihza Mahendra. Bagi Yusril, Natsir adalah seorang guru, baik dalam hal keagamaan maupun politik. Penobatannya sebagai ketua Partai Bulan Bintanganak kandung Masyumibarangkali didukung akan kemampuannya memahami pemikiran Natsir dan logika Masyumi,. Hal tersebut dapat diketahui melalui karya-karya tulisnya, yang terkesan sebagai pembela terhadap Natsir maupun Masyumi.

Sementara itu, pemikiran Muhammad Abid al-Jabiri dalam konteks Indonesia banyak mempengaruhi kaum muda Nahdlatul Ulama (NU). Hal ini disebabkan budaya pesantren -yang kebanyakan- taken for granted terhadap pemikiran ulama dahulu. Kekuatan doktrin yang membatasi pemikirannya itu, kemudian berbalik arah dengan bertanya bagaimanakah menyikapi tradisi 
sebaiknya? Petanyaan inilah yang kemudian ingin dijawab oleh mereka yang terusik pemikirannya. Dalam proses pencarian tersebut ia menemukan salah satu rujukannya dalam pemikiran al-Jabiri. Termasuk kategori kaum muda NU adalah mereka yang tergabung dalam sebuah Lembaga Kajian Islam dan Sosialdi UIN Yogyakarta. Di sisi lain, ada Ahmad Baso yang getol menyebarkan pemikiranpemikiran al-Jabiri. Ia juga termasuk kaum muda NU karena ia sendiri adalah anggota NU dan seorang santri NU. Selain itu ada Mujiburrahman dan Syafiq Hasyim yang juga rajin menerjemahkan karya al-Jabiri.

Dalam kalangan Nahdatul Ulama sendiri, Lembaga Kajian dan Pengembangan Sumber Daya Manusia (LAKPESDAM NU) menerbitkan jurnal Tashwirul Afkar yang frame pemikirannya dapat dikatakan ala al-Jabiri. Bahkan sempat terbit dengan tema Post Tradisionalisme Islam yang tidak lain rujukannya kebanyakan dari al-Jabiri. Sementara kaum muda Muhammadiyah pun mengalami hal yang sama, yaitu menjadikan pemikiran al-Jabiri sebagai bahan rujukan penting dalam diskusi-diskusi rutinnya. Tapi tidak dijadikan frame pemikirannya. Barangkali secara perorangan itu telah dilakukan. Saat ini pemikiran al-Jabiri banyak dikaji pula dalam forum-forum diskusi mahasiswa, terutama Mahasiswa di lingkungan Universitas Islam Negeri (UIN) Suka Yogyakarta. Meskipun belum bisa dikatakan seseorang yang concern dan sangat dipengaruhi al-Jabiri, akan tetapi ada beberapa artikel atau buku yang banyak mengutip al-Jabiri atau bahkan menggunakan pendekatan dekonstruksi ala al-Jabiri. Amin Abdullah, misalnya, tidak jarang dalam tulisannya mengutip al-Jabiri.dalam tulisannya ini ia menyimpulkan dalam budaya ilmu (hadârah al-'ilm) berdiri atas pondasi nalar burhani, sedangkan budaya fikih (hadârah al-fiqh) terbangun dengan teks oleh qiyas dengan cara kerja yang utama, sedang kebudayaan ilmu Filsafat(hadârah alfalsafah) terbangun atas sebuah argumen logika. Nampaknya, pemetaan seperti ini merupakan pemetaan yang telah dibahas al-Jabiri sebelumnya. Dengan demikian, pemikiran al-Jabiri bukanlah pemikiran yang muncul lalu tenggelam, akan tetapi direspon oleh banyak kalangan yang ingin memenuhi 'ambisi' intelektualnya.

\section{Simpulan}

Penyusun menyampaikan beberapa kesimpulan yang berpijak pada pokok persoalan yang telah dirumuskan dalam pemabahasan, yaitu:

Demokrasi dalam pandangan Muhammad Natsir bahwa demokrasi harus sesuaidengan nilai-nilai dasar ketuhanan. Dan M. Natsir menyepakati demokrasi dalam Islam itu adalah sepertitheistic democracy, yaitu konsep demokrasi yang dilandaskan dengan nilai-nilai ketuhanan. Keputusan oleh mayoritas rakyat yang selaras dengan nilai-nilai ketuhanan tersebut, menurut Natsir, dan demoktrasi adalah hasilijma' para ulama yang mengikat dan telah sesuai dengan perkembangan zaman tertentu. Sedangkan menurut al-Jabiri, konsep demokrasi dapat ditentukan oleh dua hal yang berbeda, Pertama otoritas dari tradisi dan yang Kedua otoritas renaissans yang telah ada. M. Abid Aljabirri membaca konsep demokrasi dan konsepsyûrâ (musyawarah) dalam Islam dan dengan membatasidari unsur-unsur demokrasi dalam perkembanagndalam perjuangan konsep demokrasi di negara-negara Eropa, yang sudah berlangsung lebih dari 3 abad.Faktor-faktor yang melatarbelangi Natsir dan al-Jabiri dalam membangun konsepnya antara lain: faktor yaitu dari latar belakang pendidikan , guru tempat mereka belajar, dan pengaruh kondisi politik di Indonesia M. Natsir dan Kondisi 
Politik di Maroko M. Abid Al-Jabirri, dan faktor ekonomi keduanya , dan metode penafsiran pendekatan mereka. Persamaan dan Perbedaan antara Natsir dan al-Jabiri. Persamaan, Pertama Keduanya sama-sama berkecenderungan substansial dalam berupaya menafsirkan Al-Qur'an dan Hadits ajaran-ajaran Islam. Kedua Keduanya sama-sama menyetujui sistem pemerintahan demokrasi yang medahulukanmementingkan,ketertiban, keadilan, dan kesejahteraan bersamabagi masyarakat dengan tidak membedakan agama, ras maupun suku bangsa. Ketiga Keduanya sama-sama berada dalam kondisi dalam negara yang tidak stabil baik secara politik maupun secara ekonomi, karenadalam tekanan jajahan kolonialisme. Di negara Indonesia dijajah Belanda dan di negara Maroko dijajah Perancis. Keempat Keduanya sama-sama dapat dikategorikan sebagai pemikir reformistik. Yaitu yakin bahwa turâs dengan modernitas sama-sama baik. dan menyatakan turâs dan modernitas telah sesuai denganakal sehat dan rasional. Perbedaaan; Pertama, Latar belakang pendidikan. Natsir tumbuh dalam lingkungan pendidikan yang bergerak dalam pembaharuan Islam, sedangkan alJabiri tumbuh dalam lingkungan pendidikan milik nasionalis. Kedua Guruguru/tokoh-tokoh yang mempengaruhi. Pemikiran Natsir banyak dipengaruhi oleh kaum modernis, semntara al-Jabiri banyak dipengaruhi oleh gerakan poststrukturalisme Perancis. Ketiga Metode pendekatan yang digunakan Natsir adalah rekonstruksi, yang menafsirkan kembali turâ̂s agar sesuai dengan keinginan zaman. Sementara al-Jabiri menggunakan metode dekonstruksi, yang membongkar struktur bangunan turâs dan modernitas. Keempat Natsir menekankan persatuan agama dan negara, dan mengatakan bahwa demokrasi sesuai dengan tradisi dan ajaran Islam, sedangkan al-Jabiri mengatakan bahwa agama dan negara bukanlah harus dipisah atau disatukan, akan tetapi memang hal ini tidak pernah dilontarkan pada zaman Nabi dan al-Khulafấ' ar-Râsyidûn. Kelima, Natsir membangun konsep demokrasinya atas dasar konsep ijtihâd, syûrâ dan ijmâ'.dalamsistem ijtihâd dan ijmâ' apabila dihubungkan dengan sistemsyûrâ yang telah terdapat dalam al-Qur'an, menurut Natsir, dapat dicapai apabila dibentuk sebuahparlemen yang dipilih langsung oleh seluruh rakyat. Dan $\mathbf{M}$. Natsir berpendapat bahwa demokrasi telah sesuai dengan kondisi masyarakat Indonesia yang benganut kedaulatan rakyat. Sementara al-Jabiri melihat demokrasi atas dasar realitas kontemporer Arab yang menuntut keadilan, tiadanya tirani, dan adanya persamaan. 


\section{DAFTAR PUSTAKA}

Abdillah, Masykuri, Demokrasi di Persimpangan Makna: Respons Intelektual Muslim Indonesia Terhadap Konsep Demokrasi (1966-1993), alih bahasa Wahib Wahab, Yogyakarta: Tiara Wacana, 1999.

Afandi, Arif (ed.), Islam Demokrasi Atas Bawah: Polemik Strategi Perjuangan Umat Model Gusdur dan Amin Rais, Yogyakarta: Pustaka Pelajar, 1997.

el-Affendi, Abdelwahab, Masyarakat Tak Bernegara, Kritik Teori Politik Islam, alih bahasa Nuruddin Arraniri, Cet. II, Yogyakarta: LKiS, 2001.

Ahmad, Mumtaz (ed.), Masalah-masalah Teori Politik Islam, alih bahasa: Ena Hadi, Bandung: Mizan, 1993.

Amir, Zainal Abidin, Peta Politik Islam Pasca Soeharto, Jakarta: LP3ES, 2003.

Amirudin, M. Hasbi, Konsep Negara Islam Menurut Fazlur Rahman, Yogyakarta: UII Press, 2000.

Azra, Azyumardi, Pergolakan Politik Islam, dari Fundamentalisme, Modernisme Hingga Post-Modernisme, Jakarta: Paramadina, 1996.

Baso, Ahmad, "Pengantar Penerjemah: Posmodernisme Sebagai Kritik Islam, Kontribudsi Metodologis "Kritik Nalar" Muhammad Abid Al-Jabiri, dalam Muhammad abid Al-Jabiri, Post Tradisionalisme Islam, Yogyakarta: LKiS, 2000.

------, "Problem Islam dan Politik: Perspektif Kritik Nalar Politik Muhammad Abid al-Jabiri,” dalam Jurnal Tashwirul Afkar, No. 4, 1999.

Hidayat, Komaruddin, "Tiga model Hubungan Agama dan Demokrasi", dalam Elza Peldi Taher, Demokratisasi Politik, Ekonomi dan Budaya, Pengalaman Indonesia Masa Orde Baru, Jakarta: Paramadina, 1994.

Huwaydi, Fahmi, Demokrasi, Oposisi dan Masyarakat Madani, Isu-Isu Besar Politik Islam, alih bahasa M. Abdul Ghafar E.M., Bandung: Mizan, 1996.

al-Jâbirî, Muhammad 'Abid, Ad-Dimuqrâiyyah wa Huqûq al-Insân, Beirût: Markaz Dirâsât al-Wihdah al-'Arabiyyah, 1994.

------, Ad-Dîn wa ad-Daulah wa Tathbîq asy-Syarî’ah, Beirût: Markaz Dirâsât alWihdah al-'Arabiyyah, 1994.

------, Post-Tradisionalisme Islam, alih bahasa Ahmad Baso,Yogyakarta: LKIS, 2000.

Mahendra, Yusril Ihza, Modernisme dan Fundamentalisme dalam Politik Islam, Perbandingan Partai Masyumi (Indonesia) dan Jamaat-i Islami 
(Pakistan), Jakarta: Paramadina, 1999.

------, "Modernisme Islam dan Demokrasi: Pandangan Politik M. Natsir", dalam Islamika Jurnal Dialog Pemikiran Islam, No. 3, Januari-Maret, 1994.

------, "Muhammad Natsir dan Sayid Abul A'la al-Maududi, Telaah tentang Dinamik Islam dan Transformasinya ke dalam Ideologi Sosial dan Politik", dalam Anwar Harjono, dkk., Pemikiran dan Perjuangan Mohammad Natsir, Jakarta: Pustaka Firdaus, 2001.

Natsir, M., Agama dan Negara dalam perspektif Islam, Endang Saefudin Anshari (penyunting), Jakarta: Media Da'wah, 2001.

Nur, Muhammad, "Islam Berbicara tentang Cita-cita Politik Indonesia Baru", dalam Jurnal Asy-Syir'ah, Vol. 36, No. I, 2002.

Pulungan, J. Suyuthi, Prinsip-prinsip dalam Piagam Madinah Ditinjau dari Pandangan al-Qur'an, Jakarta: Raja Grafindo Persada, 1994.

Raharjo, Dawam, "Agama, Islam dan Negara" dalam Mukti Ali dkk., Agama dalam Pergumulan Masyarakat Kontemporer, Imron Rasyidi (ed.), Yogyakarta: Tiara Wacana,1998.

Rahman, Fazlur, Islam, Cet. IV, Bandung: Pustaka, 2000.

----, Islam dan Modernitas, alih bahasa Ahsin Muhammad, Bandung: Pustaka, 1995.

Rahmat, Jalaluddin, "Islam dan Demokrasi”, dalam Frans Magnis-Suseno, dkk., Agama dan Demokrasi, Jakarta: Perhimpunan Pengembangan Pesantren dan Masyarakat, 1992.

Rais, M. Amien, Membangun Politik Adiluhung: Membumikan Tauhid Sosial, Menegakkan Amar Ma'ruf Nahi Munkar, Idi Subandi Ibrahim (ed.), Jakarta: Zaman Wacana Mulia, 1998.

------, Moralitas Politik Muhammadiyah, Yogyakarta: Dinamika, 1995.

Syamsudin, M. Din, "Usaha Pencarian Konsep Negara dalam Sejarah Islam", dalam Abu Zahra (ed.), Politik Demi Tuhan, Bandung: Pustaka Hidayah, 1999.

asy-Syawi, Taufiq, Syura Bukan Demokrasi, alih bahasa Jamaludin ZS., Jakarta: Gema Insani Press, 1997.

Taisir, Muhammad, Konsep Kenegaraan dalam Islam Menurut Natsir, skripsi tidak diterbitkan, Yogyakarta: Fakultas Syari'ah IAIN Sunan Kalijaga, 2002. 
Toprak, Binnaz, Islam dan Perkembangan Politik di Turki, alih bahasa Karsidi Diningrat, Yogyakarta: Tiara Wacana, 1999.

Arifin, Zaenal, Gagasan Tentang Islam sebagai Dasar Negara dalam Majlis Konstituante: Studi Perjuangan Politik Muhammad Natsir 1957-1959, skripsi tidak diterbitkan, Yogyakarta: Fakultas Adab IAIN Sunan Kalijaga, 2002.

Assyaukanie, A. Luthfi, "Tipologi dan Wacana Pemikiran Arab Kontemporer", dalam Jurnal Pemikiran Islam Paramadina, Vol. 1, No. 1, Juli-Desemder 1998.

Aziz, M. Imam, dkk. (ed.), Agama, Demokrasi, dan Keadilan, Jakarta: Gramedia, 1993.

Bekker, Anton dan Ahmad Haris Zubair, Metode Penelitian Filsafat, Cet. I, Yogyakarta: Kanisius, 1990.

Bertens, K., Filsafat Barat Abad XX, Perancis, 2 Jilid, Jakarta: Gramedia,1996.

al-Brebesy, Ma'mun Murod, Menyingkap Pemikiran Politik Gusdur dan Amin Rais tentang Negara, Jakarta: Raja Grafindo, 1999.

Budiarjo, Miriam, Dasar-dasar Ilmu Politik, Cet. XX, Jakarta: Gramedia, 1999.

----- , (ed.), Masalah Kenegaraan, Jakarta: Gramedia, 1975.

------, Partisipasi dan Parpol, Jakarta: Gramedia,1980.

al-Jâbirî, Muhammad 'Abid, Naqd al-'Aql al-'Arabi (1) Takwîn al-'Aql al-'Arabi, Cet. V, Beirût: Markaz Dirâsât al-Wihdah al-'Arabiyah, 1991.

-----, Naqd al-'Aql al-'Arabi (2) Bunyah al-'Aql al-'Arabi Cet. IV, Beirût: Markaz Dirâsât al-Wihdah al-'Arabiyah, 1992.

------, At-Turâœe wa al-Hadaceah: Dirâsah wa Munâqosyah, Beirût: Al-Markaz aœ-CEaqafi al-'Arabi, 1991.

Madjid, Nurcholish, "Demokrasi Dinamis" dalam Tekad, edisi Th.I, No.2, 9-16 November 1998.

------, "Demokrasi dan Demokratisasi di Indonesia, Beberapa Pandangan Dasar dan Prospek Pelaksanaannya sebagai Kelanjutan Logis Pembangunan Nasional”, dalam Elza Peldi Taher (ed.), Demokratisasi Politik, Budaya dan Ekonomi; Pengalaman Indonesia Masa Orde Baru, Jakarta: Paramadina, 1994. 
------, "Kebebasan Nurani (Freedom of Conscience) dan Kemanusiaan Universal sebagai Pangkal Demokrasi, Hak Asasi dan Keadilan", dalam Elza Peldi Taher, Demokratisasi Politik, Budaya dan Ekonomi, Jakarta: Paramadina, 1994 ,

------, "Pendahuluan" dalam Anwar Harjono dkk., Pemikiran dan Perjuangan Mohammad Natsir, Jakarta: Pustaka Firdaus, 2001.

Mansfield, Peter, The Arabs, New York: Penguin Books, 1990.

M.D., Moh. Mahfud, Demokrasi dan Konstitusi di Indonesia, Yogyakarta: Liberty, 1993.

Mudhofir, Ali, Kamus Teori dan Aliran dalam Filsafat dan Teologi, Yogyakarta: Gajah Mada University Press, 1996.

Mujiburrahman, "Pengantar Penerjemah: Memadukan Ibnu Rusyd dan Ibnu Khaldun", dalam al-Jabiri, Syura: Tradisi, Partikularitas, Universalitas, Yogyakarta: LKiS, 2003.

Munawwir, Ahmad Warson, Al-Munawwir, Kamus Arab-Indonesia, penelaah dan pengoreksi KH. Ali Maksum dan KH. Zainal Abidin Munawwir, Cet. XXV, Yogyakarta: Pustaka Progressif, 2002.

Nasution, Harun et.al., Perkembangan Modern dalam Islam, Jakarta: Yayasan Obor Indonesia, 1985.

Natsir, M., Capita Selecta, Jakarta: Bulan Bintang, 1973)

------, Kebudayaan Islam dalam Perspektif Sejarah, Cet. I, Jakarta: Girimukti Pasaka, 1988.

------, "Memulihkan Kepercayaan terhadap Demokrasi", dalam Herberth Feith dan Lanch Castle, Pemikiran Politik Indonesia 1945-1965, Cet. I, Jakarta: LP3ES, 1988.

------, Membangun di antara Tumpukan Puing, Jakarta: Kementrian Penerangan, 1951.

Noer, Deliar, Gerakan Moderen Islam di Indonesia, 1900-1942, Cet. VII, Jakarta: LP3ES, 1996.

------, Partai Islam di Pentas Nasional, Kisah dan Analisis Perkembangan Politik Indonesia 1945-1965, Bandung: Mizan, 2000. 